\title{
Reaksi Pasar atas Pengumuman Pemecahan Saham pada Perusahaan yang Terdaftar di Bursa Efek Indonesia
}

\author{
Ngakan Putu Wahyu Pandu Dewanata ${ }^{1}$ \\ Fakultas Ekonomi dan Bisnis \\ Universitas Udayana, Indonesia
}

\author{
I Gde Ary Wirajaya ${ }^{2}$ \\ Fakultas Ekonomi dan Bisnis \\ Universitas Udayana, Indonesia
}

Surel : wpandudewanata25@gmail.com

\section{ABSTRAK}

Penelitian ini bertujuan untuk menguji reaksi pasar yang ditimbulkan oleh pengumuman stock split. Populasi yang digunakan dalam penelitian ini berjumlah 67 perusahaan. Metode yang digunakan dalam pengambilan sampel menggunakan sampel jenuh dengan menggunakan keseluruhan perusahaan yang melakukan stock split. Data yang diperoleh merupakan data sekunder yang terdiri dari harga saham, IHSG, dan volume perdagangan saham. Dalam melakukan analisis data penelitian ini menggunakan uji One Sample T-Test dan Paired Sample T-Test. Hasil penelitian menunjukkan bahwa terdapat reaksi pasar atas pengumuman pemecahan saham (stock split) yang ditunjukkan dengan adanya abnormal return, terdapat reaksi pasar atas pengumuman pemecahan saham (stock split) yang ditunjukkan dengan adanya volume perdagangan saham, tidak terdapat reaksi pasar yang berbeda sebelum dan sesudah pengumuman pemecahan saham (stock split).

Kata Kunci: Stock Split; Abnormal Return; Likuiditas Saham.

\section{Market Reactions to the Announcement of Stock splits in Companies Listed on the Indonesia Stock Exchange}

\begin{abstract}
This study aims to examine the market reaction caused by the announcement of the stock split. The population used in this study amounted to 67 companies. The method used in sampling using saturated samples, using the entire company that did the stock split. The data obtained is secondary data consisting of stock prices, IHSG, and stock trading volume. In analyzing the data, this study used the OneSample T-Test and Paired Sample T-Test. The results showed that there was a market reaction to the announcement of a stock split as indicated by an abnormal return, there was a market reaction to the announcement of a stock split as indicated by the volume of stock trading, there is no difference in markets reaction before and after the announcement of the stock split.
\end{abstract}

Keywords: Stock Split; Abnormal Return; Stock Liquidity.

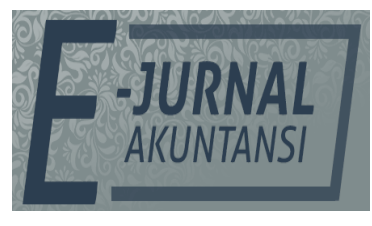

e-ISSN 2302-8556

Vol. 31 No. 10

Denpasar, Oktober 2021

Hal. 2530-2541

DOI:

10.24843/EJA.2021.v31.i10.p10

PENGUTIPAN:

Dewanata, N.P.W.P., \&

Wirajaya, I.G.A. (2021).

Reaksi Pasar atas

Pengumuman Pemecahan Saham pada Perusahaan yang

Terdaftar di Bursa Efek

Indonesia. E-Jurnal Akuntansi, 31(10), 2530-2541

RIWAYAT ARTIKEL:

Artikel Masuk:

20 Januari 2021

Artikel Diterima:

19 Mei 2021

Artikel dapat diakses : https://ojs.unud.ac.id/index.php/Akuntansi/index 


\section{PENDAHULUAN}

Pasar modal merupakan salah satu sarana alternatif yang dapat dimanfaatkan oleh para pemilik modal atau investor untuk melakukan investasi. Investor dapat memilih perusahaan mana yang nantinya mereka akan tananamkan uangnya atau modalnya agar memperoleh keuntungan maksimal. Di pasar modal, investor dapat mengetahui berbagai macam informasi, baik informasi yang tersedia di publik maupun informasi yang sifatnya privat. Salah satu informasi publik yang tersedia adalah pengumuman mengenai stock split atau pemecahan saham. Dengan adanya aksi pemecahan saham, maka investor akan menerima tambahan jumlah saham namun proporsi kepemilikan perusahaannya tidak berubah (Melati \& Andini, 2017).

Pemecahan saham (stock split) merupakan suatu kegiatan yang dilakukan oleh perusahaan publik untuk meningkatkan jumlah saham yang beredar. Kegiatan seperti itu biasanya dilakukan ketika harga dinilai terlalu tinggi sehingga akan mengurangi kemampuan investor untuk membelinya (Adisetiawan \& Atikah, 2018). Selain itu, salah satu tujuan keputusan stock split bagi pihak manajemen perusahaan adalah untuk menampung aspirasi publik agar dimilikinya harga saham yang representatif atau terjangkau untuk dimiliki (Damayanti, et al., 2014).

Harga saham yang terjangkau dapat menarik investor untuk membeli saham sehingga permintaan akan saham akan meningkat. Meningkatnya permintaan saham akan meningkatkan volume perdagangan saham, dan peningkatan permintaan saham yang terus menerus akan meningkatkan harga saham dan mempengaruhi return yang akhirnya akan meningkatkan abnormal return. Abnormal return merupakan selisih antara return sebenarnya dan return ekspektasi. Abnormal return digunakan untuk menguji reaksi dari pasar atas suatu pengumuman. Jika pengumuman tersebut mengandung informasi, maka pasar akan bereaksi dengan membentuk harga baru dari informasi yang diterima sehingga terjadilah perubahan return dan adanya abnormal return. Sebaliknya jika pengumuman tidak mengandung informasi maka tidak akan ada abnormal return.

Dengan adanya sinyal positif dari pengumuman pemecahan saham yang diterima oleh investor, sehingga membuat investor tertarik untuk membeli saham maka akan meningkatkan jumlah transaksi saham setelah pemecahan saham yang berdampak terhadap tingkat likuiditas (Aduda \& Caroline, 2010). Likuiditas saham merupakan salah satu indikator untuk melihat pasar bereaksi terhadap suatu pengumuman yang dapat dilihat dari volume perdagangan saham. Volume perdagangan saham adalah tingkat permintaan dan penawaran terhadap saham suatu perusahaan. Dalam kondisi normal, jika return saham mengalami peningkatan maka volume perdagangan juga akan meningkat. Perubahan volume perdagangan saham dipasar modal menunjukkan aktivitas perdagangan saham dan mencerminkan keputusan investasi investor.

Peristiwa pemecahan saham (stock split) sampai saat ini masih merupakan peristiwa yang penting dalam pasar modal di Indonesia, hal ini terbukti karena di setiap tahunnya beberapa perusahaan yang terdaftar di Bursa Efek Indonesia masih sering melakukan aksi pemecahan saham. Pemecahan saham merupakan fenomena yang menarik, studi tentang pemecahan saham (stock split) dan dampaknya telah dilakukan oleh beberapa peneliti terdahulu namun 
menghasilkan kesimpulan yang berbeda - beda. Penelitian ini bertujuan menguji kembali perbandingan abnormal return, likuiditas saham sebelum dan sesudah pemecahan saham.

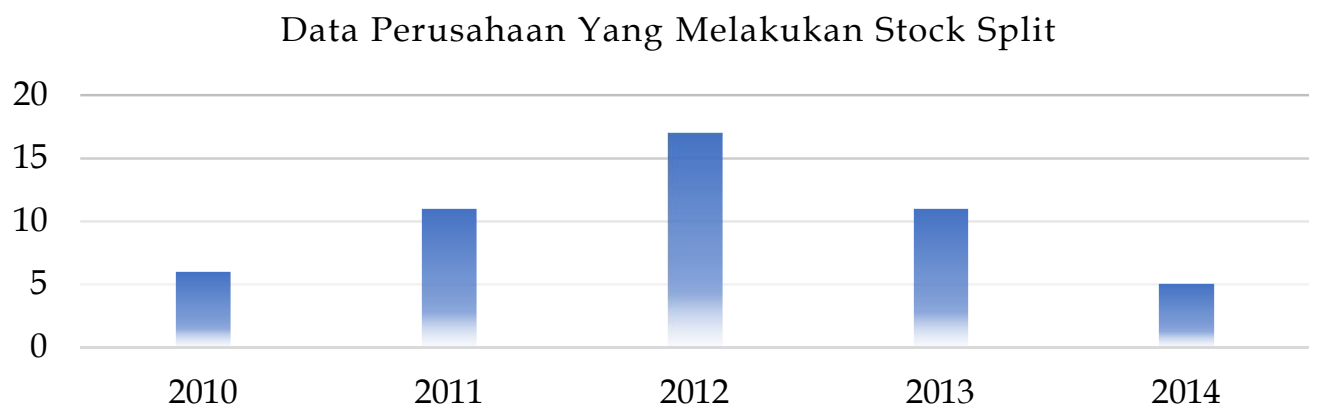

Gambar 1. Data Perusahaan yang Melakukan Stock split di Bursa Efek Indonesia

Sumber: Data Penelitian, 2020

Penelitian sebelumnya yang mengungkapkan faktor-faktor yang berkaitan dengan stock split yaitu Duarsa \& Wirama (2018) dan Vashisht (2020) menunjukan hasil bahwa terdapat perbedaan abnormal return saham yang signifikan antara sebelum dan sesudah peristiwa pengumuman stock split. Sedangkan Wulansari (2019) menunjukan tidak terdapat perbedaan signifikan antara trading volume activity sebelum dan sesudah stock split dan untuk abnormal return terdapat perbedaan signifikan antara sebelum dan sesudah peristiwa pengumuman stock split. Sandra, et al., (2018), Munthe (2017), dan How \& Tsen (2019) menunjukan hasil bahwa terdapat perbedaan abnormal return saham dan volume perdagangan saham yang signifikan antara sebelum dan sesudah peristiwa pengumuman . Sedangkan penelitian yang dilakukan oleh Patel, et al., (2016), Yustisia (2018), dan Anggarini \& Wiagustini (2015) menunjukan bahwa tidak terdapat perbedaan abnormal return saham dan volume perdagangan yang signifikan antara sebelum dan sesudah peristiwa pengumuman stock split. Penelitian yang dilakukan oleh Nyaga (2017) dan Burnwal (2019) mendapatkan hasil setelah peristiwa pemecahan saham, abornmal return dan volume perdagangan saham mengalami penurunan. Namun, penelitian yang dilakukan oleh Tabibian, et al., (2020) dan Azimatul (2019) menunjukkan hasil bahwa terdapat pengaruh stock split terhadap abnormal return dan likuiditas saham.

Berdasarkan penelitian sebelumnya terdapat ketidakkonsistenan antara teori dan praktik yang ditujukan dari research gap yang membuat penelitian tentang stock split perlu dilakukan kembali. Penulis tertarik untuk melakukan penelitian dengan mengambil judul Reaksi Pasar Atas Pengumuman Pemecahan Saham pada Perusahaan yang Terdaftar di Bursa Efek Indonesia.

Grand theory yang digunakan di penelitian ini adalah Signaling theory. Prinsip dari signaling theory adalah bahwa setiap tindakan mengandung informasi karena adanya asymetric information. Asymetric information merupakan kondisi dimana suatu pihak memiliki informasi yang lebih banyak daripada pihak lain. Misalnya pihak manajemen perusahaan memiliki informasi yang lebih banyak dibandingkan dengan pihak investor di pasar modal (Hendrawijaya, 2009). Salah satu bentuk informasi yang terdapat di pasar modal adalah stock split, stock split 
memberikan informasi kepada investor tentang prospek peningkatan return masa depan yang substansial tentang laba jangka pendek dan jangka panjang. Stock split dianggap sebagai sinyal bahwa perusahaan memiliki kinerja dan prospek yang bagus di masa yang akan datang.

Adanya pengumuman stock split membuat harga nominal saham menjadi rendah. Nilai nominal saham yang rendah diikuti dengan harga saham yang rendah pula. Harga saham yang lebih rendah membuat permintaan akan meningkat. Meningkatnya permintaan membuat harga saham akan naik sedikit demi sedikit mulai dari harga saham baru setelah stock split sesuai dengan kinerja perusahaan. Peningkatan harga saham dari hari ke hari memungkinkan terjadinya perubahan return yang akhirnya akan mengakibatkan abnormal return. Desai (2016) berpendapat bahwa investor percaya bahwa pemecahan saham akan menghasilkan kenaikan harga saham dan pembelian saham, maka harga saham cenderung akan meningkat dan menghasilkan return yang lebih. Adapun penelitian sebelumnya yang menganalisis mengenai dampak stock split yaitu (Mediyanto, 2015), (Puspita \& Yuliari, 2019) dan (Anggi \& Andhi, 2018) mendapatkan hasil bahwa terdapat perbedaan abnormal return saham antara sebelum dan sesudah perusahaan melakukan stock split. Berdasarkan uraian tersebut, dapat diperoleh hipotesis sebagai berikut.

$\mathrm{H}_{1}$ : Terdapat reaksi pasar atas pengumuman pemecahan saham yang ditujukkan dengan adanya abnormal return.

Aduda \& Caroline (2010) menyatakan bahwa saham dengan harga yang tinggi cenderung tidak likuid karena untuk alasan psikologis dan biaya transaksi. Ketika harga naik ke tingkat tertentu, para manajer membagi saham untuk menurunkan harga untuk memfasilitasi perdagangan dan harga yang murah akan menarik minat investor, sehingga dapat meningkatkan likuiditas. Meningkatnya likuiditas tercermin dari banyaknya transaksi perdagangan saham yang terjadi.

Adanya stock split diharapkan harga pasar saham mudah dijangkau oleh investor sehingga banyak saham yang dapat diperjualbelikan. Banyaknya saham yang diperjualbelikan di BEI akan membuat volume perdagangan saham meningkat sehingga saham perusahaan tersebut menjadi likuid. Dash \& Gouda (2011) menyatakan bahwa pemecahan saham mengakibatkan peningkatan likuiditas. Semakin besar frekuensi penjualannya, maka saham tersebut akan likuid. (Azimatul, 2019). (Sandra et al., 2018) menemukan hasil bahwa stock split meningkatkan likuiditas yang diwujudkan dalam volume perdagangan saham. (Leung, et al., 2019) memperoleh hasil bahwa ada peningkatan yang signifikan terhadap volume perdagangan.

$\mathrm{H}_{2}$ : Terdapat reaksi pasar atas pengumuman pemecahan saham yang ditujukkan adanya volume perdagangan saham.

Pengumuman pemecahan saham diduga mempunyai kandungan informasi yang dapat mempengaruhi reaksi pasar. Reaksi pasar tersebut ditunjukkan dengan adanya perubahan harga saham perusahaan bersangkutan yang diukur dengan abnormal return. Jika suatu pengumuman mempunyai kandungan informasi maka akan memberikan abnormal return kepada pasar. Sebaliknya, suatu pengumuman yang tidak mengandung informasi tidak memberikan abnormal return kepada pasar. 
Reaksi pasar tidak hanya ditunjukkan dengan adanya perubahan harga saham yang dilihat dari abnormal return, reaksi pasar juga dapat terlihat dari perubahan volume perdagangan saham. Dalam kondisi normal, jika return saham mengalami peningkatan maka volume perdagangan juga akan meningkat. Perubahan volume perdagangan saham di pasar modal menunjukkan aktivitas perdagangan saham dan mencerminkan keputusan investasi investor.

Hasil penelitian (Munthe, 2017) menunjukkan adanya perbedaan yang signifikan terhadap rata-rata abnormal return dan likuiditas saham sebelum dan sesudah stock split, hal ini mengindikasikan bahwa pasar bereaksi positif atas stock split. Sedangkan penelitian yang dilakukan oleh (Wulansari, 2019) menunjukkan hasil tidak terdapat perbedaan signifikan antara trading volume activity sebelum dan sesudah stock split pada perusahaan yang terdaftar di Bursa Efek Indonesia tahun 2013-2017.

$\mathrm{H}_{3}$ : Terdapat reaksi pasar yang berbeda sebelum dan sesudah pengumuman pemecahan saham (stock split).

\section{METODE PENELITIAN}

Penelitian ini dilakukan hanya pada perusahaan yang melakukan corporate action berupa stock split pada perusahaan yang terdaftar di Bursa Efek Indonesia (BEI) periode 2015 - 2019 dengan cara mengakses website Bursa Efek Indonesia yaitu pada www.idx.co.id. Populasi dalam penelitian ini adalah seluruh perusahaan yang melakukan corporate action berupa stock split yang terdaftar di Bursa Efek Indonesia (BEI) periode 2015 - 2019. Metode pengambilan sampel dalam penelitian ini menggunakan sampel jenuh dengan menggunakan keseluruhan perusahaan yang melakukan stock split.

Variabel-variabel yang digunakan dalam penelitian ini adalah tanggal pengumuman stock split tahun 2015-2019 pada perusahaan-perusahaan yang terdaftar di Bursa Efek Indonesia, abnormal return yang terjadi di seputar tanggal pengumuman stock split tahun 2015 - 2019 pada perusahaan yang terdaftar dan melakukan corporate action berupa stock split di Bursa Efek Indonesia, volume perdagangan saham yang terjadi di seputar tanggal pengumuman stock split tahun 2015-2019 pada perusahaan yang terdaftar dan melakukan corporate action berupa stock split di Bursa Efek Indonesia tahun 2015-2019. Abnormal return merupakan selisih dari expected return dengan actual return. Perhitungan abnormal return penelitian ini dengan menggunakan model yang disesuaikan-pasar yaitu market adjusted model. Adapun rumus untuk menghitung abnormal return yaitu sebagai berikut.

ARit $=$ Rit - ER

Volume perdagangan saham merupakan perbandingan antara jumlah lembar saham yang diperdagangkan pada waktu tertentu dengan jumlah lembar saham yang beredar pada waktu tertentu (Azimatul, 2019). Adapun rumus untuk menghitung volume perdagangan saham, yaitu sebagai berikut.

$\Sigma T V A(i t)=\frac{\text { jumlah saham } \mathrm{i} \text { yang diperdagangkan pada periode } \mathrm{t}}{\text { Jumlah saham yang beredar pada waktu } \mathrm{t}}$

Teknik analisa dalam penelitian ini menggunakan uji parametrik yaitu One - Sample T-Test dan Paired Sample T-Test. Untuk menguji $\mathrm{H}_{1}$ dan $\mathrm{H}_{2}$ digunakan uji statistik dengan menggunakan one sample t-test. Sedangkan untuk menguji $\mathrm{H}_{3}$ 
sebelum dan setelah stock split digunakan uji statistik dengan menggunakan paired sample t-test.

\section{HASIL DAN PEMBAHASAN}

Sebelum pengujian hipotesis, diuraikan mengenai deskripsi variabel penelitian dan uji normalitas data.

Tabel 1. Hasil Analisis Statisistik Deskriptif Average abnormal return

\begin{tabular}{cccccc}
\hline & $\mathrm{N}$ & Minimum & Maximum & Mean & Std. Deviation \\
\hline AAR Sebelum & 67 & $-0,039$ & 0,205 & 0,014 & 0,038 \\
AAR Sesudah & 67 & $-0,201$ & 0,133 & 0,002 & 0,044 \\
Valid N (listwise) & 67 & & & &
\end{tabular}

Sumber: Data Penelitian, 2020

Hasil analisis data average abnormal return sebelum pengumuman memiliki nilai minimum $-0,0389$ dan maximum 0,205 . Artinya dari 67 perusahaan yang dijadikan sampel, rata-rata abnormal return terendah dimiliki oleh PT Mahaka Radio Integra Tbk. (MARI) dan tertinggi adalah PT Sumber Energi Andalan Tbk. (ITMA) Nilai standar deviasi sebelum pengumuman yaitu 0,038, yakni mencerminkan bahwa terjadi perbedaan average abnormal return sebesar 0,038 terhadap mean.

Hasil analisis data average abnormal return sesudah pengumuman memiliki nilai minimum -0,201 dan maximum 0,133. Artinya dari 67 perusahaan yang dijadikan sampel, rata-rata abnormal return terendah dimiliki oleh PT Andira Agro Tbk (ANDI) dan tertinggi Lion Metal Works (LION) Nilai standar deviasi sesudah pengumuman yaitu 0,044 , yakni mencerminkan bahwa terjadi perbedaan average abnormal return sebesar 0,044 terhadap mean.

Tabel 2. Hasil Analisis Statisistik Deskriptif Average Trading Volume Activity

\begin{tabular}{lcrrrr}
\hline & $\mathrm{N}$ & Minimum & Maximum & Mean & Std. Deviation \\
\hline $\begin{array}{l}\text { Average TVA } \\
\text { Sebelum }\end{array}$ & 67 & 0,000 & 0,014 & 0,002 & 0,003 \\
$\begin{array}{l}\text { Average TVA } \\
\text { Sesudah }\end{array}$ & 67 & 0,000 & 0,015 & 0,001 & 0,003 \\
Valid N (listwise) & 67 & & & & \\
\hline
\end{tabular}

Sumber: Data Penelitian, 2020

Hasil analisis data average trading volume activity sebelum pengumuman memiliki nilai minimum 0,000 dan maximum 0,014. Artinya dari 67 perusahaan yang dijadikan sampel, rata-rata trading volume activity terendah dimiliki oleh PT Graha Layar Prima Tbk (BLTZ), PT Intermedia Capital Tbk (MDIA), PT Inter Delta Tbk (INTD), PT Danasupra Erapacific Tbk(DEFI), Primarindo Asia Infrastructure (BIMA), PT. Akbar Indo Makmur Stimec Tbk (AIMS) Lionmesh Prima (LION), Asuransi Jasa Tania (ASJT), PT Trust Finance Indonesia Tbk (TRUS) dan tertinggi adalah PT Sky Energy Indonesia Tbk (JSKY) Nilai standar deviasi sebelum pengumuman yaitu 0,003 , yakni mencerminkan bahwa terjadi perbedaan average trading volume activity sebesar 0,003 terhadap mean.

Hasil analisis data average trading volume activity sesudah pengumuman memiliki nilai minimum 0,000 dan maximum 0,015. Artinya dari 67 perusahaan yang dijadikan sampel, rata-rata trading volume activity terendah dimiliki oleh PT Graha Layar Prima Tbk(BLTZ), Primarindo Asia Infrastructure (BIMA), PT Trust 
Finance Indonesia Tbk (TRUS), PT Danasupra Erapacific Tbk(DEFI), dan tertinggi adalah PT Surya Toto Indonesia Tbk (TOTO) Nilai standar deviasi sebelum pengumuman yaitu 0,003 , yakni mencerminkan bahwa terjadi perbedaan average trading volume activity sebesar 0,003 terhadap mean.

Tabel 3. Hasil Uji Normalitas Average abnormal return

\begin{tabular}{lcc}
\hline & AAR Sebelum & AAR Sesudah \\
\hline$N$ & 67 & 67 \\
Asymp.Sig (2-tailed) & 0,200 & 0,200 \\
\hline
\end{tabular}

Sumber: Data Penelitian, 2020

Tabel 3, menunjukkan bahwa nilai Asymp. Sig (2-tailed) average abnormal return sebelum dan sesudah adanya pengumuman stock split adalah berturut-turut sebesar 0,200 dan 0,200. Nilai signifikansi tersebut lebih besar dari level of significant 5 persen $(0,05)$ sehingga data yang digunakan dalam penelitian ini berdistribusi normal. Adapun hasil Uji Normalitas untuk average Trading Volume Activity sebelum dan sesudah pengumuman stock split dapat dilihat pada Tabel 4 .

Tabel 4. Hasil Uji Normalitas Average Trading Volume Activity

\begin{tabular}{lcc}
\hline & ATVA Sebelum & ATVA Sesudah \\
\hline $\mathrm{N}$ & 67 & 67 \\
Asymp.Sig (2-tailed) & 0,200 & 0,200 \\
\hline
\end{tabular}

Sumber: Data Penelitian, 2020

Tabel 4, menunjukkan bahwa nilai Asymp. Sig (2-tailed) Trading Volume Activity sebelum dan sesudah adanya peristiwa stock split adalah berturut-turut sebesar 0,200 dan 0,200. Nilai signifikansi tersebut lebih besar dari level of significant 5 persen $(0,05)$ sehingga data yang digunakan dalam penelitian ini berdistribusi normal.

Tabel 5. Hasil Uji One Sample T-Test Abnormal Return

\begin{tabular}{|c|c|c|c|c|c|c|}
\hline & \multirow[t]{2}{*}{$t$} & \multirow[t]{2}{*}{ Df } & \multirow{2}{*}{$\begin{array}{l}\text { Sig. (2- } \\
\text { tailed) }\end{array}$} & \multirow{2}{*}{$\begin{array}{c}\text { Mean } \\
\text { Difference }\end{array}$} & \multicolumn{2}{|c|}{$\begin{array}{l}95 \text { persen Confidence } \\
\text { Interval of the Difference }\end{array}$} \\
\hline & & & & & Lower & Upper \\
\hline $\begin{array}{l}\text { Abnormal } \\
\text { Return }\end{array}$ & 2.251 & 66 & 0,028 & 0,009 & 0,001 & 0,017 \\
\hline
\end{tabular}

Return

Sumber: Data Penelitian, 2020

Berdasarkan Tabel 5, menjelaskan ringkasan hasil pengujian abnormal return pada periode amatan yaitu $\mathrm{t}-3$ hingga $\mathrm{t}+3$. Hasilnya menunjukan bahwa abnormal return memperoleh nilai $t=2.251$ dengan probabilitas sebesar $0,028<\alpha(0,05)$ yang berarti hipotesis pertama diterima. Hasil pengujian hipotesis pertama dalam penelitian ini dengan menggunakan Uji Statistik One Sample T-Test menyatakan bahwa terdapat pengaruh stock split terhadap abnormal return. Hasil penelitian ini memberikan makna bahwa stock split memberikan informasi kepada investor tentang prospek peningkatan return masa depan yang substansial tentang laba jangka pendek dan jangka panjang dan dianggap sebagai sinyal bahwa perusahaan memiliki kinerja dan prospek yang bagus di masa yang akan datang. Adanya pengumuman stock split membuat harga nominal saham menjadi rendah, nilai nominal saham yang rendah diikuti dengan harga saham yang rendah pula. Harga saham yang lebih rendah membuat permintaan akan meningkat. Meningkatnya permintaan membuat harga saham akan naik sedikit demi sedikit mulai dari harga saham baru setelah stock split sesuai dengan kinerja perusahaan. 
Peningkatan harga saham dari hari ke hari memungkinkan terjadinya perubahan return yang akhirnya akan mengakibatkan abnormal return. Hasil analisis ini sejalan dengan penelitian yang dilakukan oleh (Azimatul, 2019) yang menyatakan bahwa terdapat pengaruh pengumuman stock split terhadap abnormal return.

Tabel 6. Hasil Uji One Sample T-Test Trading Volume Activity

\begin{tabular}{|c|c|c|c|c|c|c|}
\hline & \multirow[t]{2}{*}{$t$} & \multirow[t]{2}{*}{$\mathrm{df}$} & \multirow{2}{*}{$\begin{array}{l}\text { Sig. }(2- \\
\text { tailed })\end{array}$} & \multirow{2}{*}{$\begin{array}{c}\text { Mean } \\
\text { Difference }\end{array}$} & \multicolumn{2}{|c|}{$\begin{array}{l}95 \text { persen Confidence } \\
\text { Interval of the Difference }\end{array}$} \\
\hline & & & & & Lower & Upper \\
\hline $\begin{array}{l}\text { Trading } \\
\text { Volume } \\
\text { Activity }\end{array}$ & 4,642 & 66 & 0,000 & 0,001 & 0,000 & 0,002 \\
\hline
\end{tabular}

Sumber: Data Penelitian, 2020

Berdasarkan Tabel 6, menjelaskan ringkasan hasil pengujian trading volume activity pada periode amatan yaitu $\mathrm{t}-3$ hingga $\mathrm{t}+3$. Hasilnya menunjukan bahwa trading volume activity memperoleh nilai $\mathrm{t}=4.642$ dengan probabilitas sebesar 0,000 $<$ a $(0,05)$ yang berarti hipotesis kedua diterima. Hasil pengujian hipotesis kedua dengan menggunakan Uji One Sample T-Test menyatakan bahwa terdapat pengaruh stock split terhadap trading volume activity. Hasil penelitian ini memberikan makna bahwa pengumuman stock split menunjukkan bahwa investor memberikan feedback yang cepat terhadap informasi yang diterimanya. Investor menganggap peristiwa pemecahan saham merupakan informasi yang bagus karena pada saat pengumuman stock split banyak investor yang berani memasuki pasar dan melakukan transaksi saham .

Berdasarkan Signaling Theory yang menyatakan bahwa kebijakan perusahaan melakukan stock split adalah untuk menggambarkan tentang kondisi suatu perusahaan yang sehat terutama dari segi keuangan perusahaan yang bisa berupa laba perusahaan yang meningkat maupun kenaikan dividen dimasa yang akan datang. Menariknya, informasi stock split tersebut menyebabkan perdagangan saham likuid karena investor semakin berminat untuk melakukan transaksi dan membeli saham dengan harga murah. Harga saham yang terjangkau sebagai akibat dari adanya stock split akan menarik minat para investor untuk membeli saham perusahaan tersebut, yang nantinya akan berdampak pada volume perdagangan saham. Hasil analisis ini sejalan dengan penelitian yang dilakukan oleh Leung, et al., (2019) yang memperoleh hasil bahwa ada peningkatan yang signifikan terhadap volume perdagangan akibat adanya stock split.

Tabel 7. Hasil Paired Sample T-Test Abnormal Return \& Trading Volume Activity

\begin{tabular}{ccc} 
Activity & Sig. & Keterangan \\
\hline Variabel & 0,109 & \\
AAR - Sebelum & $\mathrm{H}_{3}$ ditolak \\
AAR - Sesudah & 0,429 & \\
$\begin{array}{c}\text { ATVA - Sebelum } \\
\text { ATVA - Sesudah }\end{array}$ & & \\
\hline
\end{tabular}

Sumber: Data Penelitian, 2020

Tabel 7, menunjukkan bahwa nilai signifikansi average abnormal return sebelum dan sesudah peristiwa stock split adalah sebesar 0,109, sedangkan nilai signifikansi Average Trading Volume Activity sebelum dan sesudah peristiwa stock 
split adalah sebesar 0,429. Nilai signifikansi sebesar 0,109 dan 0,429 lebih besar dari level of significant 5 persen $(0,05)$, sehingga dapat disimpulkan bahwa H0 diterima dan $\mathrm{H}_{3}$ ditolak. Hasil pengujian hipotesis ketiga dalam penelitian ini dengan menggunakan Uji Paired Sample T-Test mendapatkan hasil bahwa tidak terdapat reaksi pasar yang berbeda sebelum dan sesudah pengumuman pemecahan saham (stock split). Berdasarkan dari hasil penelitian bahwa peristiwa stock split tidak membawa kandungan informasi sehingga signaling theory tidak sesuai dengan hasil penelitian. Signaling theory menyatakan bahwa pengumuman stock split dianggap sebagai sinyal yang baik yang diberikan oleh perusahaan kepada publik bahwa perusahaan memiliki prospek bagus di masa yang akan datang dimana hal tersebut dapat ditunjukkan dengan adanya dampak positif pada abnormal return dan trading volume activity sesudah stock split. Tidak adanya perbedaan reaksi pada abnormal return dan trading volume activity sebelum dan sesudah stock split berarti bahwa pengumuman stock split tidak mengindikasikan sinyal yang baik mengenai keuntungan dimasa yang akan datang. Selain itu, tidak adanya perbedaan reaksi pasar sebelum dan sesudah stock split dapat disebabkan faktor eksternal seperti adanya isu - isu yang mempengaruhi keadaan pasar atau keadaan ekonomi negara sehingga investor cenderung melakukan strategi wait and see (Fauzi et al., 2016). Hasil ini juga didukung penelitian yang dilakukan oleh Michael Hendrawidjaya (2009) yang menyatakan bahwa signaling theory tidak selamanya berlaku pada peristiwa stock split karena hasil pengujian hipotesis membuktikan bahwa tidak terdapat perbedaan abnormal return dan volume trading volume activity sebelum dan sesudah pengumuman stock split.

\section{SIMPULAN}

Berdasarkan hasil analisis, simpulan yang dapat disampaikan adalah 1) terdapat reaksi pasar atas pengumuman pemecahan saham (stock split) yang ditujukkan dengan adanya abnormal return, 2) terdapat reaksi pasar atas pengumuman pemecahan saham (stock split) yang ditujukkan dengan adanya volume perdagangan saham, 3) tidak terdapat reaksi pasar yang berbeda sebelum dan sesudah pengumuman pemecahan saham (stock split).

Saran bagi peneliti selanjutnya yaitu, disarankan untuk menambah sampel perusahaan, periode penelitian serta dapat menambahkan jenis industri perusahaan. Selain itu, peneliti selanjutnya juga diharapkan menghitung abnormal return menggunakan model selain Market Adjusted Model seperti Mean-Adjusted Model ataupun Market Model.

\section{REFERENSI}

Adisetiawan, R., \& Atikah. (2018). Does stock split influence to liquidity and stock return? (empirical evidence in the Indonesian capital market). Asian Economic and Financial Review, 8(5).

Aduda, J. O., \& Caroline, C. (2010). Market Reaction to Stock splits Empirical Evidence from the Nairobi Stock Exchange. African Journal of Business $\mathcal{E}$ Management (AJBUMA), 1.

Anggarini, D., \& Wiagustini, P. (2015). Dampak Pemecahan Saham Terhadap Likuditas dan Abnormal Return di Bursa Efek Indonesia. 
Anggi, N., \& Andhi, W. (2018). Pertumbuhan dan Ukuran Perusahaan pada Stock split. Management Analysis Journal, 1(2).

Azimatul, U. (2019). Pengaruh Pemecahan Saham (Stock split) Terhadap Abnormal Return dan Likuditas Saham pada Perusahaan Bertumbuh dan Tidak Bertumbuh. Jurnal Akuntansi Dan Auditing Indonesia, (5), 55.

Burnwal, A. (2019). Announcement Effect of Stock split on Price Behaviour and Market Liquidity of Shares : a Study. XI(Xii).

Chavali, K., \& Zahid, Z. (2011). Impact of stock splits on stock price performance of selected companies in Indian context. Afro-Asian Journal of Finance and Accounting, 2(3), 270-282.

D.Bhuvaneswhari, \& K.Ramya. (2014). Impat of Stock split Announcement on Stock Prices. Use of Social Media to Attract and Engage New Customer Base, 5(3).

Damayanti, N. L., Atmadja, A. T., \& Surya, N. A. (2014). Analisis Pengaruh Pemecahan Saham (Stock split) terhadap Tingkat Keuntungan (Return) Saham dan Likuiditas Saham (Studi pada Perusahaan yang Go Public di Bursa Efek Indonesia. Jurnal Ilmiah Mahasiswa Akuntansi S1, 2(1), 10.

Dash, M., \& Gouda, A. (2011). A Study on the Liquidity Effects of Stock splits in Indian Stock Markets. SSRN Electronic Journal.

Desai, J. (2016). Impat of Stock split on Share Prices. International Journal of Recent Scientific Research, 7(5).

Duarsa, O. G., \& Wirama, D. G. (2018). Pengaruh Ukuran Perusahaan dan Split Ratio pada Respon Pasar terhadap Stock split. E-Jurnal Akuntansi, 23.

El Ansary, O. A. E., \& El-Azab, M. H. (2017). The Impact of Stock Dividends and Stock splits on Shares' Prices: Evidence from Egypt. Accounting and Finance Research, 6(4), 96.

Fama, E. F. (1970). Session Topic: Stock Market Price Behavior Session Chairman: Burton G. Malkiel Efficient Capital Markets: A Review Of Theory And Empirical Work. The Journal of Finance, 25(2), 383-417.

Fauzi, S., Suhadak, S., \& Hidayat, R. (2016). Pengaruh Pengumuman Stock split Terhadap Likuiditas Saham dan Return Saham (Studi pada Perusahaan yang Terdaftar di Bursa Efek Indonesia Periode 2012-2014). Jurnal Administrasi Bisnis 11 Universitas Brawijaya, 38(2), 156-162.

Gunaasih, S. A. P. P. (2015). The Evaluation of Non-Economic Events towards the LQ-45 Index in Indonesia Stock Exchange by Using Event Study Method. Review of Integrative Business E Economics Research, 4(2), 106-120.

Hartono M, J. (2015). Teori portofolio dan analisis investasi (edisi Kesepuluh). In Yogyakarta: BPFE.

Hendrawijaya, M. (2009). Analisis Perbandingan Harga Saham, Volume Perdagangan Saham dan Abnormal Return Saham Sebelum dan Sesudah Pemecahan Saham ( Studi pada perusahaan go public yang melakukan pemecahan saham antara tahun 2005 - 2008 di BEI ). Jurnal Manajemen Dan Akuntansi.

How, C. C., \& Tsen, W. H. (2019). The Effects of Stock split Announcements on the Stock Returns in Bursa Malaysia. Jurnal Ekonomi Malaysia, 53(2), 1-14.

Jogiyanto. (2010). Teori Portofolio dan Analisis Investasi. Yogyakarta: BPFEYogyakarta. 
Leung, T. Y., Rui, O. M., \& Wang, S. S. (2019). Do Stock splits Really Signal? In SSRN Electronic Journal.

Mediyanto, M. E. (2015). Pengaruh Stock split Terhadap Abnormal Return dan Volume Perdagangan (Stock split Effect Of Abnormal Return And Trading Volume ). Artikel Ilmiah Mahasiswa, 1-7.

Melati, \& Andini, N. (2017). Analisis Reaksi Pasar Terhadap Stock split pada Perusahaan Bertumbuh dan Tidak Bertumbuh. Jurnal Ilmu Manajemen, 13(2), 1-25.

Munthe, K. (2017). Perbandingan Abnormal Return Dan Likuditas Saham Sebelum Dan Sedudah Stock split: Studi Pada Perusahaan Yang Terdaftar Di Bursa Efek Indonesia. Jurnal Akuntansi, 20(2).

Nugraha, N. I., \& Wijayati, F. L. (2018). Peristiwa Stock split: Analisis Aktivitas Perdagangan Saham Dan Return Saham Pada Perusahaan Di Bursa Efek Indonesia Tahun 2015-2017. Jurnal Akuntansi Syariah.

Nyaga, P. N. (2017). the Effect of Stock split Announcements on Share Prices of a Dissertation Submitted in Partial Fulfilment of the Requirements for the Award of Master of Commerce ( Finance and Accounting ) Degree in the School of Business and Public. Journal Finance and Accounting, 1(1), 3-84.

Purbawati, T. D., Arifati, R., \& Andini, R. (2016). Pengaruh Pemecahan Saham (Stock split) Terhadap Trading Volume Activity dan Average abnormal return Pada Perusahaan Yang Terdaftar Di Bursa Efek Indonesia. Journal Of Accounting, 2(2), 1-12.

Puspita, N. V., \& Yuliari, K. (2019). Analisis Pengaruh Stock split Terhadap Harga Saham, Abnormal Return Dan Risiko Sistematik Saham Perusahaan (Studi Pada Perusahaan Yang Terdaftar Di Bei 2016-2018). Ekonika : Jurnal Ekonomi Universitas Kadiri, 4(1), 95.

Putra, P. G. A., \& Suaryana, I. G. N. A. (2019). Reaksi Pasar Atas Pengumuman Stock split. E-Jurnal Akuntansi, 27, 1448.

Sadalia, I., \& Silalahi, A. S. (2019). Analysis of Information Content in the Event of Stock split on the Indonesia Stock Exchange. International Journal of Research and Review, 6(August), 243-251.

Sandra, A. Z., Amin, M., \& Junaidi. (2018). Analis Pengaruh Stock split Terhadap Harga Saham (Studi Pada Perusahaan Yang Terdaftar Di BEI 2014-2017). E-JRA Vol. 07 No. 12 Agustus 2018, 07(12), 87-96.

Satria, K., \& Adnan. (2018). Analisis Peristiwa Stock split Terhadap Harga Saham, Likuiditas Saham dan Abnormal Return (Studi Kasus pada Perusahaan Manufaktur yang Terdaftar di Bursa Efek Indonesia Tahun 2011 - 2015). 3(3), 364-384.

Sugiyono. (2018). Metode Penelitian Kuantitatif,Kualitatif dan R\&D. Ke-26.

Tabibian, S. A., Zhang, Z., \& Jafarian, M. (2020). How does split announcement affect stock liquidity? Evidence from bursa Malaysia. Risks, 8(3), 1-14.

Tandelilin, E. (2010). Portofolio dan Investasi. In Kanisius (p. 219).

Vashisht, A. (2020). Impact of Stock splits on Trading Volume a nd Shareholders ' Wealth- An Empirical Study. UGC Care Journal, 40(23), 54-72.

Wahyudi, K., \& Asmara, W. (2020). Perbandingan Reaksi Pasar pada Perusahaan LQ45 dan Non LQ45 atas Pengumuman Stock split Kadek. E-Jurnal Akuntansi, 21(1), 307-318. 
Wiagustini. (2010). Dasar - dasar Manajemen Keuangan. Denpasar: Udayana University Press.

Wijanarko, I. (2012). Analisis Pengaruh Pemecahan Saham ( Stock split) Terhadap Likuiditas Saham Dan Return Saham. In Diponegoro Journal of Managemen (Vol. 1).

Wulansari, D. A. (2019). Analisis Perbedaan Trading Volume Activity Dan Abnormal Return Saham Sebelum Dan Sesudah Peristiwa Stock split Pada Perusahaan Yang Terdaftar Di Bursa Efek Indonesia Tahun 2013-2017. Jurnal Manajemen Dan Bisnis Universitas Muhammadiyah Surakarta.

Yustisia, N. (2018). The Impact of Stock split on the Performance in Indonesian Manufacturing Companies. Binus Business Review, 9(1), 39. 